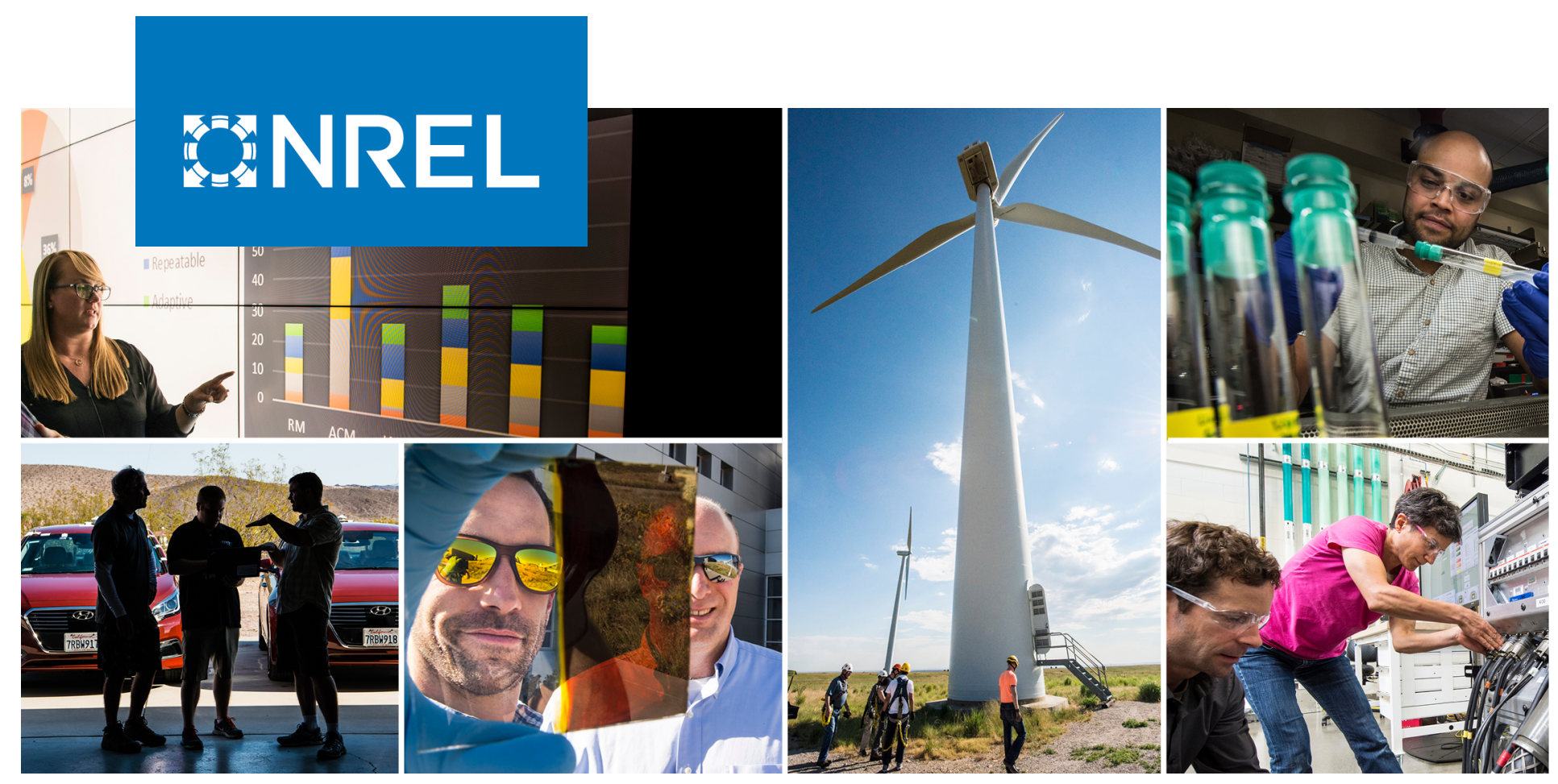

\title{
Best Practices at the End of the Photovoltaic System Performance Period
}

Taylor Curtis, ${ }^{1}$ Garvin Heath, ${ }^{1}$ Andy Walker, ${ }^{1}$ Jal Desai, ${ }^{1}$ Edward Settle, ${ }^{1}$ and Cesar Barbosa ${ }^{2}$

${ }^{1}$ National Renewable Energy Laboratory

${ }^{2}$ NuLife Power

NREL is a national laboratory of the U.S. Department of Energy Office of Energy Efficiency \& Renewable Energy

Operated by the Alliance for Sustainable Energy, LLC

This report is available at no cost from the National Renewable Energy Laboratory (NREL) at www.nrel.gov/publications.
Technical Report

NREL/TP-5C00-78678

February 2021 


\title{
GNREL
}

\section{Best Practices at the End of the Photovoltaic System Performance Period}

\author{
Taylor Curtis, ${ }^{1}$ Garvin Heath, ${ }^{1}$ Andy Walker, ${ }^{1}$ Jal Desai, ${ }^{1}$ \\ Edward Settle, ${ }^{1}$ and Cesar Barbosa ${ }^{2}$ \\ ${ }^{1}$ National Renewable Energy Laboratory \\ ${ }^{2}$ NuLife Power
}

\section{Suggested Citation}

Curtis, Taylor, Garvin Heath, Andy Walker, Jal Desai, Edward Settle, and Cesasr

Barbosa. 2021. Best Practices at the End of the Photovoltaic System Performance Period.

Golden, CO: National Renewable Energy Laboratory. NREL/TP-5D00-78678.

https://www.nrel.gov/docs/fy210sti/78678.pdf.

NREL is a national laboratory of the U.S. Department of Energy Office of Energy Efficiency \& Renewable Energy Operated by the Alliance for Sustainable Energy, LLC

This report is available at no cost from the National Renewable Energy Laboratory (NREL) at www.nrel.gov/publications.

Contract No. DE-AC36-08G028308
Technical Report NREL/TP-5D00-78678 February 2021

National Renewable Energy Laboratory 15013 Denver West Parkway Golden, CO 80401 303-275-3000 • www.nrel.gov 


\section{NOTICE}

This work was authored in part by the National Renewable Energy Laboratory, operated by Alliance for Sustainable Energy, LLC, for the U.S. Department of Energy (DOE) under Contract No. DE-AC36-08GO28308. Funding provided by U.S. Department of Energy Office of Energy Efficiency and Renewable Energy Solar Energy Technologies Office Award Number 34172. The views expressed herein do not necessarily represent the views of the DOE or the U.S. Government.

This report is available at no cost from the National Renewable Energy Laboratory (NREL) at www.nrel.gov/publications.

U.S. Department of Energy (DOE) reports produced after 1991 and a growing number of pre-1991 documents are available free via www.OSTI.gov.

Cover Photos by Dennis Schroeder: (clockwise, left to right) NREL 51934, NREL 45897, NREL 42160, NREL 45891, NREL 48097, NREL 46526.

NREL prints on paper that contains recycled content. 


\section{Notice}

This report was prepared as an account of work sponsored by an agency of the United States Government. Neither the United States Government nor any agency thereof, nor any of their employees, makes any warranty, express or implied, or assumes any legal liability or responsibility for the accuracy, completeness, or usefulness of any information, apparatus, product, or process disclosed, or represents that its use would not infringe privately owned rights. Reference herein to any specific commercial product, process, or service by trade name, trademark, manufacturer, or otherwise does not necessarily constitute or imply its endorsement, recommendation, or favoring by the United States Government or any agency thereof. The views and opinions of authors expressed herein do not necessarily state or reflect those of the United States Government or any agency thereof.

\section{Acknowledgments}

This material is based upon work supported by the U.S. Department of Energy's Office of Energy Efficiency and Renewable Energy (EERE) under the Solar Energy Technologies Office Award Number 34172. 


\section{List of Acronyms}

CESA

EPA

EPEAT

FMV

IEEE

IRENA

IRS

ITC

NREL

NYSERDA

O\&M

PPA

PV

RCRA

SEIA

TCLP
Clean Energy States Alliance

U.S. Environmental Protection Agency

Electronic Product Environmental Assessment Tool

fair market value

Institute of Electrical and Electronic Engineers

International Renewable Energy Agency

Internal Revenue Service

investment tax credit

National Renewable Energy Laboratory

New York State Energy Research and Development Authority operation and maintenance

power purchase agreement

photovoltaic

Resource Conservation and Recovery Act of 1976

Solar Energy Industries Association

Toxicity Characteristic Leaching Procedure 


\section{Executive Summary}

Responsible and cost-effective dissolution of photovoltaic (PV) system hardware at the end of the performance period has emerged as an important business and environmental consideration. Alternatives include extending the performance period and existing contracts for power purchase, lease, and utility interconnect; refurbishing the plant by correcting any deficiencies; repowering the plant with new PV modules and inverters; or decommissioning the plant and removing all the hardware from the site. Often key decisions are made very early in the project development and might require decommissioning by some certain date after the end of a power purchase agreement. To "abandon in place" is not an alternative acceptable to landowners and regulators, so any financial prospectus should include costs associated with decommissioning, even if those costs are deferred by extending operations, refurbishment, or repowering. Decommissioning costs are driven by regulations regarding the handling and disposal of waste, with reuse and recycling of PV modules and other components preferred as a way to reduce both costs and environmental impact. Each alternative is discussed with order-of-magnitude costs, and recommendations are provided considering site-specific details of that situation, such as estimated costs to refurbish or repower, projected revenue from continued operations, and tax considerations. 


\section{Table of Contents}

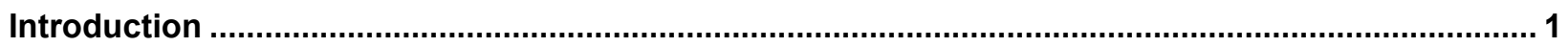

1 Alternatives at the End of the Performance Period ................................................................ 3

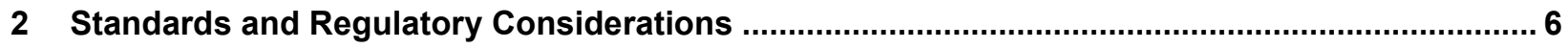

2.1 Reusing and Repairing for Reuse Regulatory Considerations ................................................ 6

2.2 Recycling and Disposal Regulatory Considerations ............................................................. 7

2.2.1 Regulatory Exclusions from the Definition of Solid Waste.......................................... 7

2.2.2 Resource Conservation and Recovery Act Hazardous Waste Determination ................... 7

2.2.3 Regulation of Photovoltaic System Material as Hazardous Waste ............................... 8

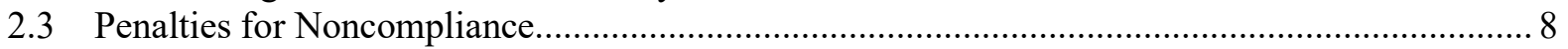

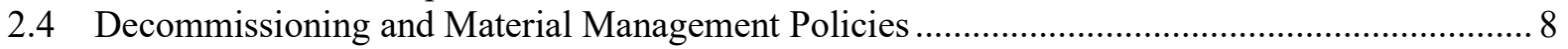

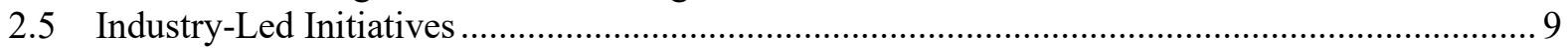

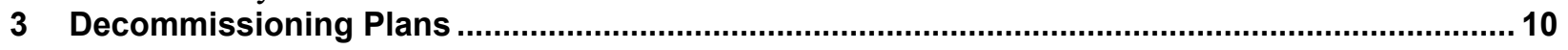

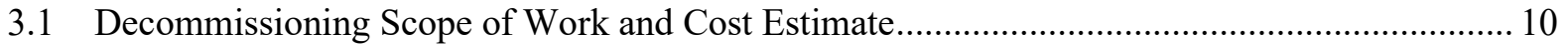

Table 2. Example Cost Estimates for Decommissioning per 1-MW PV System (fixed tilt rack)

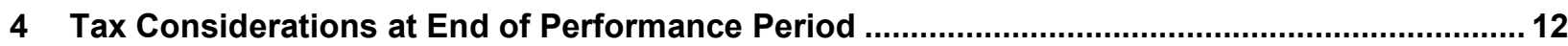

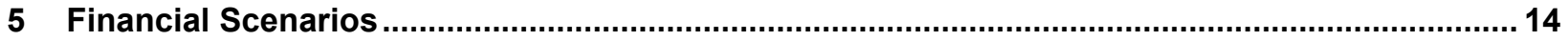

6 Challenges and Recommended Best Practices .................................................................... 17

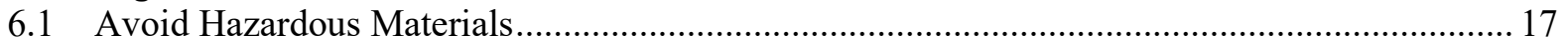

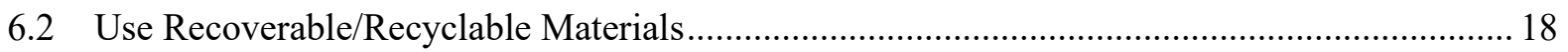

6.3 Recycle Photovoltaic Modules and Other Recyclable Materials ............................................. 18

6.4 Include End of PV Performance Period Issues in Contract Terms........................................... 18

6.5 Plan a Contingency if the Responsible Party Is Unable to Perform Decommissioning .............. 19

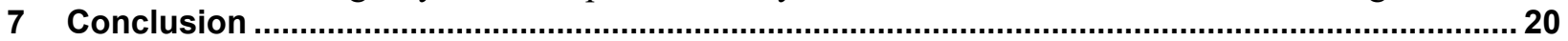

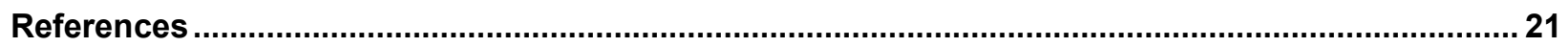




\section{List of Figures}

Figure 1. Example cash flow analysis showing a BaseCase of decommissioning in year 25, Extend Case of extending the performance period to 40 years through continued O\&M, Refurbish Case wherein repairs are made in year 25 to restore recoverable degradation, and a Repower Case where a major investment in new PV modules and inverter restores both recoverable and non-recoverable degradation and resets the PV module and inverter warranties. Figure by the author....

\section{List of Tables}

Table 1. Advantages and Disadvantages of End-of-Performance Period Alternatives. (Existing arrangements refer to power purchase, land use, and utility interconnection contracts.)....... 5

Table 2. Example Cost Estimates for Decommissioning per 1-MW PV System (fixed tilt rack) 11 


\section{Introduction}

A photovoltaic (PV) power generation project involves design, construction, and operation of a PV power plant over a performance period of 20-30 years. The duration of a financial prospectus or power purchase agreement (PPA) often determines the expected performance period. This paper investigates alternatives at the end of that performance period: extending the performance period and refurbishing, repowering, or decommissioning the system, as well as laws that can limit these options. The installation of PV systems has grown exponentially, with an estimated 20,000 MW of capacity to be installed in the United States in 2020 (Feldman, O'Shaughnessy, and Margolis 2020). At approximately 60 metric tons of PV modules per megawatt (IRENA 2016), modules installed in 2020 will eventually result in more than 1 million tons of PV modules to be managed for reuse or disposal. Because sustainability is a major driver behind the PV market, PV plant owners and operators would like disposal waste to be minimized and managed properly. To "abandon in place" an inoperative system is not acceptable to landowners or local authorities. Concerned by the magnitude of the disposal waste, many environmental management authorities are already promulgating regulations requiring the proper handling, storage, and final disposition of PV system waste.

A nascent industry is turning this liability into a business opportunity. New companies are specializing in services such as resale of used PV modules and parts, decommissioning, and recycling. These services are an important and growing part of the PV industry. Donations of used PV modules for redeployment by legitimate charitable entities might even be eligible for a tax deduction, increasing the appeal of a repowering proposal. Strategies to reduce waste include increasing plant efficiency to reduce the number of modules required and enhancing maintenance to reduce early failures and extend module lifetimes; reusing modules through refurbishment and for use in lower value applications; and recycling to recover embodied materials.

Issues that arise and costs that are incurred at the end of a PV project life cycle should be considered at the earliest stages of project planning and in the financial prospectus for the project. Often decisions are delayed until the future, but this frequently leaves one of the remaining project parties with additional, end-of-life costs. In cases where contracts did not address end-of-performance-period issues, it is recommended to prepare plans and modify contracts to deal with decommissioning. Contracts such as land leases might be extended if both parties agree or terminated at the end of their term by one party. Utility interconnection agreements and permits to operate might be renewed, renegotiated, or terminated. A PPA might be extended, modified, or terminated. Ownership of the system might change (tax rules might require this sale at fair market value to avoid looking like an installment purchase rather than lease or power purchase agreement). Alternatives for a PV system physical plant at the end of the performance period include extending existing contracts and operations and refurbishing, repowering, or decommissioning the system.

If the PV system is owned by the building owner, the system might continue to deliver power past the expected performance period, but declining performance or the end of a contract will be a trigger for the site owner to consider refurbishing, repowering, or decommissioning it. At any time in a project life, a severe storm might cause enough damage to compel the same decisions 
as those faced by owners of old systems. The need to reroof a building is another trigger, with many owners finding it more cost-effective to remove the older system and install a new one rather than reinstall the old equipment. (Many contractors also refuse to offer or warrant reinstallation of old equipment.) Manufacturing defects or breakage in shipping or installation are other reasons that modules are disposed.

This paper describes the need to plan early in project development, issues to consider at the end of the performance period, and the pros and cons of alternatives. It also includes recommendations for system owners, asset managers, and industry service providers. 


\title{
1 Alternatives at the End of the Performance Period
}

Alternatives that arise at the end of the expected performance period of a PV plant include extending contracts and operations for an additional period, making an investment to refurbish the system to correct deficiencies, repowering the system with new PV modules and inverters, or decommissioning and removing a system from the site.

1. Extending the performance period: If a system is operational and has not suffered extensive damage, it might be possible to continue operations past the original planned performance period. This could involve:
A. Extending the PPA
B. Extending the utility interconnection agreement - if it was of limited term
C. Extending any operating permits or land-use permits that will expire
D. Possibly transferring system ownership (title) to the site owner or to a third party
E. Acknowledging that the system will have suffered degradation in performance that will continue and could accelerate as the equipment ages
F. Recognizing that operation-and-maintenance (O\&M) costs will increase for the aging equipment - perhaps to unaffordable amounts as spare parts become unavailable.

2. Refurbishing the System: Refurbishing a system that been inspected and repaired involves:
A. Performing detailed physical and electrical inspections and testing to identify any problems
B. Fixing any deficiencies, including replacing failed components
C. Replacing parts of an old system that might become increasingly hard to find and expensive
D. Acknowledging that staff might not have expertise with older equipment, software, and maintenance procedures
E. Recognizing that there can be no upgrade of capabilities or standards
F. Assuming that the cost for refurbishing could be approximately $\$ 500 / \mathrm{kW}^{1}$ If the system has suffered storm damage, the cost could exceed $\$ 750 / \mathrm{kW}^{1}$ (from an example with $30 \%$ of the modules replaced).
G. Accepting that the intent of the refurbishment might be to operate the system for an additional 10 or 15 years
H. Recognizing that PV modules have degraded and will continue to degrade.

\begin{abstract}
Necessary repairs often include replacing failed modules with compatible PV modules; replacing inverter parts or perhaps entire inverters as well as gaskets and closures on cabinets; replacing broken fuse holders and obtaining new fuses; repairing racks, including eroded piles; reinstalling wire management ties; replacing tracking parts (if in original design); removing vegetation, including large trees; enhancing ground cover and storm water runoff; and reinspecting or recommissioning a refurbished system.
\end{abstract}

\footnotetext{
${ }^{1}$ Based on the authors' experience assessing PV systems on a military base in Colorado
} 
Refurbishment could also involve rearranging series strings of PV modules to contain only good modules and rearranging inverter connections to use only good strings, thus "cannibalizing" a poorly performing system into a smaller but well-performing system. For example, following a hailstorm in Colorado that damaged 30\% of the PV modules in a PV system that consisted of $96 \mathrm{PV}$ modules and two inverters, the author recommended rearranging and optimizing the two arrays, fully powering one of the two $15-\mathrm{kW}$ inverters, disposing of the broken modules, and saving the second inverter as a spare.

3. Repowering the System: Rebuilding or replacing the power source of a power plant involves:

A. Redesigning to accommodate new design objectives related to power, maintainability, safety, and security

B. Installing a new PV array to take advantage of the improved efficiency, thermal degradation, and physical strength of new PV modules

C. Installing one or more new inverters to take advantage of advanced control capabilities and the reliability of new technology

D. Leveraging existing land-use, permitting, utility interconnections, and favorable power purchase prices or incentives to improve the prospects compared to a new PV project

E. Recognizing that the cost of repowering could be from $\$ 1,000 / \mathrm{kW}$ to $\$ 1,500 / \mathrm{kW}$. Repowering often carries a cost of $80 \%$ of the total plant value $(\$ 1,600$ to $\$ 2,000$, NREL 2020), to be eligible for the Investment Tax Credit per the Internal Revenue Service (IRS 2018)

F. Acknowledging that repowering could allow operations to continue for an additional 20 years or more.

Repowering results in a PV system that is new in almost all respects. The advantage of repowering over constructing a new plant is in the existing land-use permit and lease and savings in the site selection, utility interconnection, and civil works - such as access road and grading — and perhaps reuse of any buildings, equipment pads, or foundations on-site.

4. Decommissioning: Removing a plant from active service and rendering it to a safe and final state involves:

A. Removing the PV array

B. Removing the balance-of-plant (such as racks, foundations, and enclosures)

C. Restoring the land or roof to its original condition or adapting it to a new use, such as a parking lot

D. Recognizing that the costs of decommissioning could be from $\$ 300 / \mathrm{kw}$ to $\$ 440 / \mathrm{kW}$, with the difference being a credit of $\$ 40 / \mathrm{kW}$ if the PV modules can be repurposed and resold versus $a$ cost of $\$ 100 / \mathrm{kW}$ to recycle the modules (Barbosa 2020). 
Table 1. Advantages and Disadvantages of End-of-Performance Period Alternatives. (Existing arrangements refer to power purchase, land use, and utility interconnection contracts.)

\begin{tabular}{|c|c|c|c|c|}
\hline Alternative & Extend & Refurbish & Repower & Decommission \\
\hline \multirow[t]{4}{*}{ Advantage } & $\begin{array}{l}\text { Defers disposal } \\
\text { costs }\end{array}$ & $\begin{array}{l}\text { Restores some } \\
\text { lost performance }\end{array}$ & $\begin{array}{l}\text { Enhances } \\
\text { performance with } \\
\text { new technology }\end{array}$ & $\begin{array}{l}\text { Frees land and } \\
\text { other assets for } \\
\text { subsequent use }\end{array}$ \\
\hline & $\begin{array}{l}\text { No capital } \\
\text { investment }\end{array}$ & $\begin{array}{l}\text { Leverages } \\
\text { existing plant and } \\
\text { arrangements }\end{array}$ & $\begin{array}{l}\text { Leverages } \\
\text { existing }\end{array}$ & $\begin{array}{l}\text { Discontinues } \\
\text { expenses }\end{array}$ \\
\hline & $\begin{array}{l}\text { Leverages } \\
\text { existing } \\
\text { arrangements }\end{array}$ & & $\begin{array}{l}\text { infrastructure and } \\
\text { arrangements }\end{array}$ & \\
\hline & & & $\begin{array}{l}\text { Low maintenance } \\
\text { costs }\end{array}$ & \\
\hline \multirow[t]{2}{*}{ Disadvantage } & $\begin{array}{l}\text { Degraded } \\
\text { performance }\end{array}$ & $\begin{array}{l}\text { Some capital } \\
\text { investment }\end{array}$ & $\begin{array}{l}\text { Higher capital } \\
\text { investment }\end{array}$ & $\begin{array}{l}\text { Incurs } \\
\text { decommission } \\
\text { costs }\end{array}$ \\
\hline & $\begin{array}{l}\text { High } \\
\text { maintenance } \\
\text { costs }\end{array}$ & $\begin{array}{l}\text { High } \\
\text { maintenance } \\
\text { costs }\end{array}$ & & $\begin{array}{l}\text { Forfeits existing } \\
\text { arrangements }\end{array}$ \\
\hline
\end{tabular}




\section{Standards and Regulatory Considerations}

Decisions regarding alternatives at the end of the performance period are often limited by regulations that arise in project development and that are promulgated by local city, town, and county laws related to plan reviews, construction permits, permits to operate, land-use permits, community planning and zoning, and others. Such laws often include conditions that must be met at the end of the performance period in connection with the issuance of permits by the authority having jurisdiction; waivers of some requirements; and possibly language that requires financial mechanisms to be in place - such as a performance bond or other surety - to ensure that a financial resource is available for the final disposition of the system, even if the original parties are not able to perform it (e.g., have gone out of business) (NYSERDA 2020). Decommissioning mandates might require approved decommissioning plans to be included in the initial approval for construction and operation.

Other regulations regard handling waste. Whether refurbishing, repowering, or decommissioning, system owners and operators recognize and evaluate material management options for PV modules and system components. Owners and operators observe the laws that apply to their specific jurisdiction in determining the best end-of-performance-period option. Management options for retired and end-of-life PV system materials include reusing, repairing for reuse, recycling, storing, and disposing. System owners consider the financial and legal liability associated with each material management option. Federal, state, and local laws or regulations might mandate a specific management disposition for PV system material, such as PV modules, and they might also mandate specific handling, transportation, and storage requirements for PV modules and other system components that carry civil and criminal liabilities for noncompliance. In the absence of federal, state, or local laws or regulations, voluntary industry standards (detailed below) could also provide a roadmap to reuse or recycle PV system materials (Curtis et al. 2021a).

\subsection{Reusing and Repairing for Reuse Regulatory Considerations}

The reuse and repair for reuse of PV modules and system components might be limited for use in new systems by state and local interconnection, fire, building, electric, and equipment regulations in certain applications. For example, some U.S. jurisdictions - such as California, Independent System Operator - New England, and Hawaii - that have incorporated the Institute of Electrical and Electronic Engineers (IEEE) 1547 equipment standard and the UL 1741 testing standard into their interconnection regulations may effectively prohibit the reuse of older PV modules for grid-tied rooftop and ground-mounted applications if they do not use smart inverters or if the design is otherwise out of compliance (Curtis et al. 2021a; IEEE 2018). Similarly, state and local fire and building regulations might also impact the reuse of PV modules and system components for certain grid-tied rooftop applications. For example, U.S. jurisdictions that have adopted Section 1509.7.2 of the International Code Council's International Building Code as a fire and building regulation, such as California, can effectively prohibit the reuse of older PV modules that do not meet the same fire rating classification as the roof covering (Curtis et al. 2021a). In certain jurisdictions, state and local electrical regulations can also prohibit the reuse of PV modules and other system components, such as inverters in rooftop and building-mounted grid-tied and off-grid applications. For example, jurisdictions that have adopted the National Fire Protection Association's National Electric Code Section 690.12 
as regulation would prohibit the reuse of PV modules and/or inverters that are not equipped/updated rapid-shutdown devices (Curtis et al. 2021a; CESA 2017).

\subsection{Recycling and Disposal Regulatory Considerations}

Retired and end-of-life PV modules and system components that are not reused are subject to federal, state, and local solid waste requirements (Curtis et al. 2021a; Curtis et al. 2021b; 42 U.S.C. § 6903(27); 40 C.F.R. § 261.2(e)(1)(ii)). Specifically, retired and end-of-life PV modules and system components accumulated or stored before recycling or disposal, and those being recycled or disposed of may be regulated as solid waste or potentially hazardous waste pursuant to the Resource Conservation and Recovery Act of 1976 (RCRA) (40 C.F.R. $\S \S$ 261.2(a)-(c); 42 U.S.C. $§ 6903(27)$; 40 C.F.R. $\S 261.2(e)(i i))$. RCRA is the federal law that regulates solid and hazardous waste in the United States, and solid waste regulated under RCRA is defined as "discarded material" to include materials "disposed of," "burned or incinerated," or "recycled" or "accumulated, stored, or treated before or in lieu of being disposed of" (40 C.F.R. $\S \S 261.2(\mathrm{a})-(\mathrm{c}) ; 42$ U.S.C. $\S 6903(27) ; 40$ C.F.R. $\S 261.2(\mathrm{e})(\mathrm{ii}))$. Studying the bill of materials and literature might indicate if a PV module contains hazardous materials, and it can be determined by testing.

\subsubsection{Regulatory Exclusions from the Definition of Solid Waste}

Depending on the jurisdiction, certain regulatory exclusions might apply for PV system materials that are recycled. The federal RCRA program outlines a few regulator exclusions specific to the type of materials being recycled, the recycling process being used, and how the recovered resources are used (Curtis et al. 2021a). For example, the ballasts and frames from a PV system might fall under a scrap metal exclusion if that material is recycled (Curtis et al. 2021 a; 40 C.F.R. $\S 261.4(a)(13)$ ). In addition, PV system material that is transferred for reclamation in the United States or exported from the United States for reclamation, provided certain regulatory requirements are met, might also be excluded from RCRA regulations (Curtis et al. 2021a; 40 C.F.R. $\S \S 261.4(\mathrm{a})(24)-(25)$ ). Note that not all states have adopted these federal RCRA program exclusions. Almost all states that administer their own hazardous waste programs pursuant to RCRA have the authority to include requirements beyond the federal RCRA program, and therefore they might choose not to adopt the federal RCRA exclusions (EPA 2019a; EPA 2019b).

\subsubsection{Resource Conservation and Recovery Act Hazardous Waste Determination}

If an exclusion, exemption, or other provision does not apply, PV system materials meeting the definition of solid waste might also be regulated as hazardous waste if they exhibit one or more hazardous characteristics. For example, PV modules might contain materials (e.g., cadmium, telluride, and lead) that at times have been reported to exceed U.S. federal- or state-mandated toxicity thresholds, subjecting those modules to hazardous waste regulation.

PV system owners and operators are obligated under federal and state RCRA regulations to determine if their end-of-life PV modules exhibit a hazardous characteristic. They might determine if the modules are hazardous through "acceptable knowledge" or through testing. Examples of acceptable knowledge include "process knowledge (e.g., information about chemical feedstocks and other inputs to the production process); knowledge of products, byproducts, and intermediates produced by the manufacturing process; chemical or physical 
characterization of wastes; information on the chemical and physical properties of the chemicals used or produced by the process or otherwise contained in the waste; testing that illustrates the properties of the waste; other reliable and relevant information about the properties of the waste or its constituents" (Curtis et al. 2021a; 40 C.F.R. §261.11(d)(1)). If adequate knowledge is not apparent, the PV system owner must test the PV module, using an approved testing method, to determine if it is hazardous. Currently, the Toxicity Characteristic Leaching Procedure (TCLP) is the main federally approved testing method used to determine if a PV module exceeds toxicity thresholds triggering hazardous waste regulation (Curtis et al. 2021a; 40 C.F.R. $\S \S$ $262.11,261.24)$. Note that the TCLP has led to varying results - even when testing the same make and model of a PV module, the results seem largely dependent on the sampling location, removal method used, and the laboratory used to analyze the results (Curtis et al. 2021a; Leslie 2018). States with the authority to administer their own hazardous waste program might also implement more stringent testing requirements. For example, in California, a PV module must also be analyzed using the total digestion and Waste Extraction Test. There is evidence that PV modules have passed the federal TCLP test, failed the Waste Extraction Test, and were therefore regulated as California-only hazardous waste, requiring the PV modules to be regulated in California as hazardous (Curtis et al. 2021a).

\subsubsection{Regulation of Photovoltaic System Material as Hazardous Waste}

PV system owners follow stringent handling requirements when storing, recycling, or disposing of PV modules classified as hazardous waste (Curtis et al. 2021a; 40 C.F.R. § 260.10). Depending on the quantity of hazardous waste PV modules accumulated at one time, a PV system owner might need to acquire a U.S. Environmental Protection Agency (EPA) identification number, provide a manifest for the transport of the PV modules, comply with personnel training requirements, and comply with on-site accumulation and storage time limits (Curtis et al. 2021a; 40 C.F.R. $§ 260.10$ ).

\subsection{Penalties for Noncompliance}

Noncompliance with any RCRA provision could result in civil and criminal liabilities. In terms of compliance with federal RCRA requirements, the EPA has the authority to issue a civil penalty up to $\$ 101,449$ per violation per day, a criminal penalty up to $\$ 50,000$ per violation per day, and/or up to 2 years in prison for noncompliance (40 C.F.R. $\S 19.4$ ). State penalties for violating state hazardous waste regulations might be more stringent than the federal penalties.

\subsection{Decommissioning and Material Management Policies}

System owners might also need to comply with state and local decommissioning and PVspecific material management policies. Some states - including Washington, California, New Jersey, and North Carolina - are starting to adopt policies that address PV system decommissioning and material management requirements. Moreover, several states — including Arizona and Hawaii-have pending legislative bills that, if enacted, would create PV system decommissioning and material management disposition requirements (Curtis et al. 2021a).

The policies in these states are diverse and impact different life-cycle activities and actors in the PV value chain. Washington is the only state with a mandate requiring the reuse or recycling of retired PV modules. Although the onus is on the module manufacturer, PV system owners need to coordinate with the manufacturer or a designated stewardship organization to ensure that 
decommissioned modules are reused or recycled. Washington's law, which goes into effect July 1, 2023, requires PV module manufacturers to finance and implement a take-back program to reuse or recycle at least $85 \%$ of PV modules sold into the state at no cost to the consumer (Wash. Rev. Code § 70A.510.010(5)). In contrast, California's regulation, which went into effect in January 2021, would directly impact the system owner and their handling, transportation, and storage of retired PV modules. California's regulation would allow PV modules that exhibit hazardous characteristics to be regulated as universal waste. Universal waste is a subset of hazardous waste that generally has less stringent management requirements than fully regulated hazardous waste, and which might reduce the costs and liabilities associated with PV module recycling and disposal (Curtis et al. 2021a; 40 C.F.R. $\S \S 260-265,273$ ). New Jersey and North Carolina recently passed policies to study and develop regulations related to PV system decommissioning and module disposition (2019 N.C. Sess. Law 2019-132; 2019 N.J. Sess. Law Serv. Ch. 215 (West)).

\subsection{Industry-Led Initiatives}

There are also several industry-led initiatives that PV system owners should consider at the end of the system performance period. International voluntary stewardship standards - such as NSF/ANSI 457 and U.S. national industry-led efforts from the Solar Energy Industries Association (SEIA) - could aid system owners in material management decision making. SEIA's National PV Recycling Program provides a network of cost-effective recyclers that can offer collection, transportation, and recycling services to system owners for retired modules and other system components (SEIA 2019b). SEIA also provides guidance for system owners that want to recycle retired PV system equipment (SEIA 2019c). Voluntary industry standards, such as NSF/ANSI 457 Sustainability Leadership Standard for Photovoltaic Modules and Photovoltaic Inverters, can also provide a detailed description on how to reuse or recycle PV modules and inverters instead of disposing them. The NSF/ANSI 457 standard establishes sustainable performance criteria and corporate performance metrics, which include categories for end-of-life management and corporate responsibility, exemplify sustainable leadership in the solar market (NSF International 2019; Curtis et al. 2021b). The NSF/ANSI 457 standard was recently listed on the Electronic Product Environmental Assessment Tool (EPEAT) registry, which is an online IT sector eco-label tool managed by the Green Electronics Council (GEC) to help purchasers evaluate and compare sustainable products (EPEAT 2019). PV owners can obtain certification through an audit process to demonstrate compliance with sustainability measures. System owners that pursue a sustainability standard, such as NSF/ANSI 457, could increase consumer trust in their company's sustainability practices and enhance their competitiveness (Curtis et al. 2021a; Curtis et al 2021b). Industry participation in this program is nascent. 


\section{Decommissioning Plans}

Decommissioning plans appear as provisions in land-use agreements (land lease, easement, right-of-way, etc.), might be required for construction and operating permits, and should be recorded with a registrar of deeds. These provisions arise in initial construction approval requirements and are negotiated between the landowner and the solar developer but might need to comply with local (town, city, county) laws. Decommissioning plans should include (NYSERDA 2020):

1. Contact information for all parties (landowner; solar developer; authorities having jurisdiction; and known sources of services, such as recycling programs and emergency service providers)

2. Any warranted recycling of PV modules or other components that were provisioned as part of the original procurement; any bonds to take back PV modules or other equipment

3. Conditions that trigger the decommissioning (date certain, end of lease, system inoperative for 12 months, any other)

4. Time period within which the decommissioning must be completed (e.g., 6 months)

5. Scope of work for the decommissioning, which often includes removing all equipment, grading to restore water runoff characteristics, restoring ground cover (seed), or otherwise restoring the land to its original condition

6. Roles and responsibilities of the landowner, solar developer, and any other parties clearly delineated.

\subsection{Decommissioning Scope of Work and Cost Estimate}

A decommissioning scope of work reads like an installation scope of work in reverse (Lundt 2019). Instead of unpacking and installing modules, one is removing them and packing them for shipment. Labor cost might be half the installation labor cost. PV modules are stacked on pallets or put into shipping containers; metal rack parts are often put into roll-off dumpsters sorted by aluminum, steel, and copper. Major pieces of equipment, such as inverters or transformers, might be sourced for spare parts or recycling. Similar to installation, a crane would be required to remove materials from a rooftop system. Costs vary widely, but Table 2 provides example cost estimates based on the details of a decommissioning scope of work.

Decommissioning cost ranges from $\$ 300 / \mathrm{kW}$ to $\$ 440 / \mathrm{kW}$, with the difference being a credit of $\$ 40 / \mathrm{kW}$ if the PV modules can be repurposed and resold, versus a cost of $\$ 100 / \mathrm{kW}$ to recycle the modules (Barbosa 2020). 
Table 2. Example Cost Estimates for Decommissioning per 1-MW PV System (fixed tilt rack)

\begin{tabular}{lc}
\hline Item & $\begin{array}{c}\text { Cost Estimate } \\
(\$ / \mathbf{M W})\end{array}$ \\
\hline Make arrangements for recycling or sale of used items & $\$ 2,000$ \\
Provide lavatories and safety items & $\$ 5,000$ \\
Rent containers to sort recyclables and disposables & $\$ 5,000$ \\
Remove and bundle array wiring and AC wiring & $\$ 25,000$ \\
Remove and palletize PV modules & $\$ 25,000$ \\
Dismantle racks and containerize & $\$ 50,000$ \\
Remove and palletize combiner boxes and disconnects & $\$ 25,000$ \\
Remove conduit and containerize & $\$ 25,000$ \\
Remove and disassemble inverter & $\$ 50,000$ \\
Remove transformer & $\$ 75,000$ \\
Truck to recycling center & $\$ 5,000$ \\
Truck to landfill & $\$ 5,000$ \\
Hazardous waste disposal & $\$ 5,000$ \\
\hline
\end{tabular}

\section{For rooftop systems:}

Rent crane or telehandler for rooftop systems (\$225/day) $\$ 4,500$

Repair roof for rooftop systems $\$ 50,000$

For ground-mounted systems:

Install temporary fence (\$20/ft) \$10,000

Break up and remove concrete pads for ground-mounted $\$ 25,000$ systems

Remove ground screws and power poles $\$ 40,000$

Remove temporary fence $\$ 5,000$

Grading $\$ 20,000$

Seed disturbed areas $\quad \$ 16,000$

Salvage values:

PV modules $\$(40,000)$

Copper wire and parts $\$(20,000)$

Transformer and switchgear $\$(15,000)$

Aluminum rack and parts $\$(15,000)$

Total for rooftop system \$306,500

Total for ground-mounted system $\$ 368,000$ 


\section{Tax Considerations at End of Performance Period}

Tax issues are complex, and readers are encouraged to seek professional tax advice. At the beginning of a solar PPA or lease contract, terms are written that affect the options at the end of the performance period and that incorporate considerations that secure federal tax incentives, including an investment tax credit (ITC) and accelerated depreciation benefits. Since the Energy Policy Act of 2005, the ITC has been valued at $30 \%$ of the eligible tax basis (most or all the system cost) and is now being extended but expected to eventually decline annually to a permanent $10 \%$ for commercially owned systems (it will go to zero for homeowners).

Accelerated depreciation allows a system owner to deduct depreciation expenses in a short time compared to the actual expected life of the system (IRS 2018).

The IRS can recapture a portion of these incentives during the first 6 years of a project's operating life if the system fails to maintain eligibility. For example, if the contract terms effectively indicate that the system is owned by a nontaxable customer because the PPA or lease contract is more akin to a loan or installment purchase, the PPA provider is not eligible for the federal tax incentives. To avoid this situation, the contract might specify at the beginning that the system can be purchased by the customer no sooner than in year 7 or may be purchased at the end of the contract (e.g., 20 years), and the purchase and transfer of the title must be at fair market value (FMV). Otherwise, the contract might specify that the system owner will remove the system at the end of the contract period.

Although the initial contract might specify transfer at FMV to meet IRS requirements, actual transfer in the post-contract period might follow a different course (for example, if the responsible party declares bankruptcy). Additionally, the perspective of FMV might be different for the system owner than the customer. The system owner and their appraiser might want to estimate FMV primarily based on the income approach. For this approach, because the system is still producing, for example, $80 \%$ of the nameplate capacity and will continue to deliver energy savings to the customer for several years, the FMV of the system might be indicated by the present value of future savings, which could be very high in places with high power prices or lucrative incentives. The customer and their appraiser, however, might recognize that the O\&M risk, lack of profit motive, insurance requirements, obsolescence, and other factors point to an FMV that is best indicated by a discounted cost or market approach. Using these approaches, the FMV of the system might be very low. It is the responsibility of the appraiser to select and apply the method to establish FMV.

A fair end-of-contract negotiation between the buyer and the seller will include the fact that if the customer elects not to buy the system at FMV, then the system owner will need to remove it at a financial cost. In a legitimate IRS-acceptable contract, the system owner would have decided on this decommissioning option at the beginning of the contract. On the other hand, the system owner might hold the permit to operate, so the system would need to be shut down (pending new permits and interconnection agreements) if the performance contract was not extended and if operating permits and the interconnection agreement could not be transferred to the customer. To alleviate uncertainty, many contracts require the system to be decommissioned and removed at the end of the performance period if the customer does not purchase the system or extend the contract with the system owner even though that might be costly to the owner and 
not the best outcome environmentally in terms of renewable energy production and solid waste disposal.

An IRS requirement that affects the decision to repower a PV system at the end of the performance period is that for a system to be eligible for the ITC, at least $80 \%$ of the cost must be for new equipment ("original use"). That requirement limits the amount of equipment that can be reused in a repowering at the same site, or the tax benefits that used equipment entails if it is reused in another site. In all likelihood, the value of modules in a 20 -year-old system is less than $20 \%$ of a new system and therefore would not preclude eligibility for the ITC. Regarding depreciation, the purchaser of a $100 \%$ used system would not get the ITC but would get $100 \%$ bonus depreciation on the cost, which is a good deal for tax mitigation. Further, the Tax Cuts and Jobs Act of 2017 extended 100\% bonus depreciation to used equipment until January 1, 2023 (EERE 2020). 


\section{Financial Scenarios}

Figure 1 illustrates an example of what these end-of-performance period alternatives look like in a cash flow analysis, which can help inform decisions in terms of life-cycle cost and levelized cost of energy. This example represents a per-megawatt analysis of a utility-scale plant. Lifecycle cost analysis is conducted according to ASTM E917 and E1185, which specify how cost estimates are inflated to a future cost and how future costs are discounted to sum a net present value. Annual O\&M costs are estimated using the PV O\&M Cost Model (Walker et al. 2020), which estimates that costs would be very low, at $\$ 5 / \mathrm{kW} /$ year, in the early years, but O\&M costs increase over time because inflation increases parts and labor costs, and the real cost increases because warranties expire and the failure distributions for each component show increasing failure rates as the equipment ages. High O\&M costs in late system life are a major driver in decisions to decommission, refurbish, or repower a PV system. The spreadsheet used to generate this example is included with this paper as supplementary material.

In the BaseCase, the system is decommissioned in year 25 , by which time the energy production has dropped to $79 \%$ of the year 1 system, and the O\&M cost has increased to $\$ 40 / \mathrm{kW} / \mathrm{year}$. The decommissioning cost of $\$ 300 / \mathrm{kW}$ will have inflated to $\$ 500 / \mathrm{kW}$, and this decommissioning expense adds approximately $\$ 10 / \mathrm{MWh}$ to the levelized cost of energy, for a total of $\$ 71.55 / \mathrm{MWh}$. In the Extend Case, we model operation as continuing with both declining energy delivery and increasing O\&M cost and we assume the performance period is extended without major modifications to the system. By year 40 in the Extend Case, the production has dropped to $68 \%$ of new, and the O\&M cost has increased to $\$ 80 / \mathrm{kW} /$ year inclusive of costs associated with inverter and other major components distributed over the years). Although this O\&M cost seems prohibitively high, there is economic benefit in avoiding capital investment for refurbishment or repowering and benefit in foisting the decommissioning costs 15 years into the future. Degradation in the BaseCase and Extend Case is taken at 1\%/year- $0.6 \%$ in nonrecoverable degradation and $0.4 \%$ year in recoverable degradation. In the Refurbish Case, we reset the recoverable degradation; and in the Repower Case, we reset both the recoverable and non-recoverable degradation because a repowered plant would have new PV modules. We also reset the PV module and inverter warranties in the Repower Case. The ASTM life-cycle cost standard (ASTM 2012) caps the maximum analysis period at 40 years, so the benefit of an additional 10 years or so of production and the ultimate decommissioning cost are not included in the Repower Case (the method implies that these revenues and costs occurring in excess of 40 years in the future would appear in a subsequent analysis to inform decisions in the future), and the levelized cost of energy is thus calculated at $\$ 71.28 / \mathrm{MWh}$.

A basic tenant of the life-cycle cost analysis procedure is to make decisions based on the current situation regardless of the past costs (avoid the "sunk cost fallacy"). Even if you have invested a lot in the plant in the past, a decision should be based on the prospectus of future cash flows and economics; however, decisions affecting actions at the end of the performance period are often made in the initial contracting for the plant, requiring that decision to be informed by cost estimates that are at best approximate and change depending on how O\&M is conducted during the entire performance period. For example, a decision to decommission in year 25 might be made assuming a low power sales price $(\$ / \mathrm{kWh})$, but if power sales price increase significantly, it might be better to extend the performance period, refurbish, or repower a plant. Another observation is that because of the discounting of future costs in the life-cycle cost analysis 
procedure, the effect of decommissioning, refurbishing, or repowering a plant 25 years into the future is attenuated by the time value of money.

This example life cycle cost analysis is presented to illustrate the features that distinguish the four alternatives considered: when investments are made, the magnitude of the investments, and the effects on resulting O\&M costs and energy production and revenue. The most important implications of the life cycle cost analysis are to point out the need to include these end-ofperformance-period costs in decision making and to map out a long-term course that may extend beyond the scope and duration of the original contracts and associated periods-ofperformance. LCOE is offered as a metric to compare the alternatives even with different performance periods, but there are issues beyond LCOE that drive decisions such as legal, permitting, tax, cash-flow considerations, and other issues. 

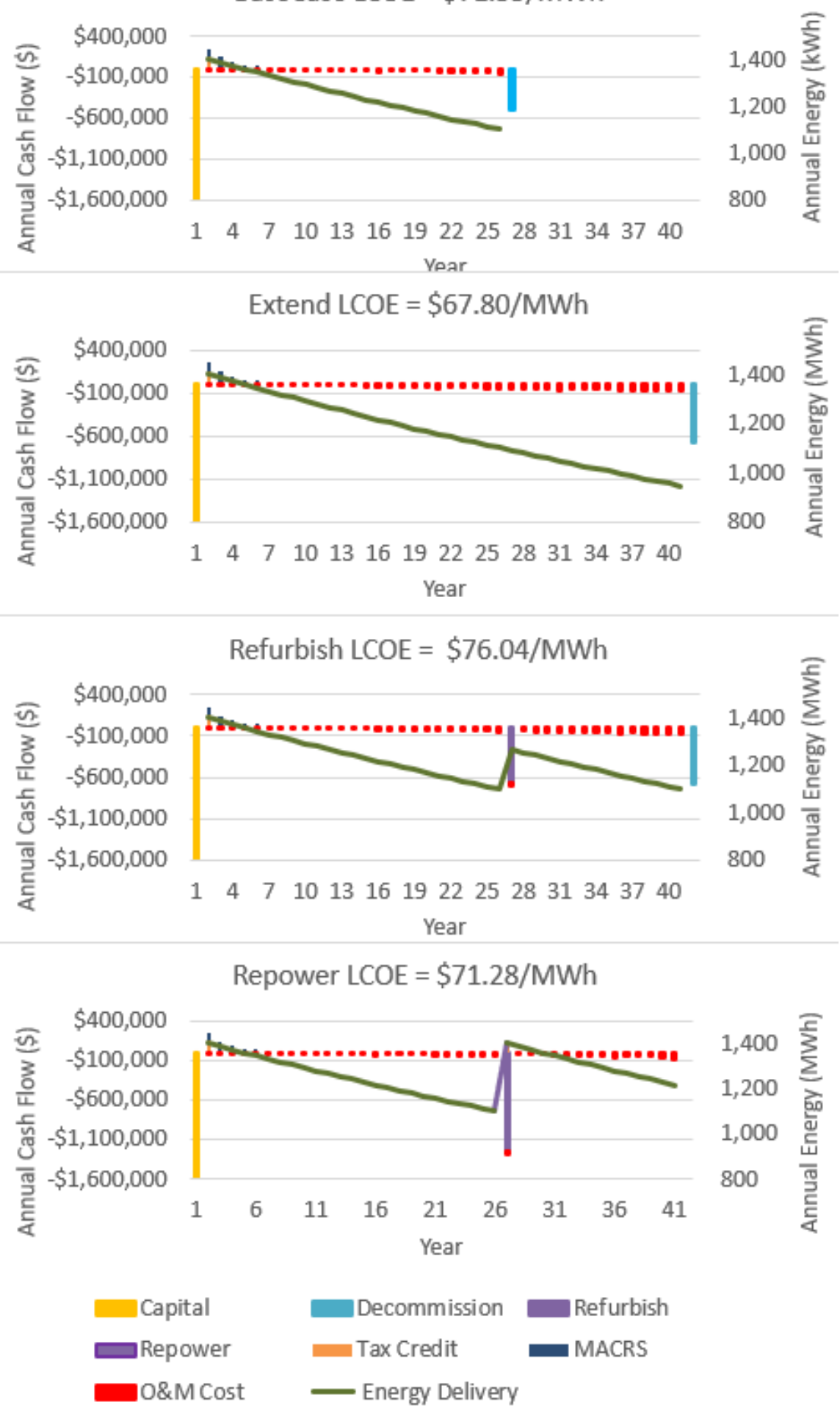

Figure 1. Example cash flow analysis showing a BaseCase of decommissioning in year 25, Extend Case of extending the performance period to $\mathbf{4 0}$ years through continued O\&M, Refurbish Case wherein repairs are made in year 25 to restore recoverable degradation, and a Repower Case where a major investment in new PV modules and inverter restores both recoverable and non-recoverable degradation and resets the PV module and inverter warranties. Figure by the author 


\section{Challenges and Recommended Best Practices}

Begin with the end in mind. End-of-performance period issues are often framed much earlier: in the financing plans; in the design and specification of components; and in ongoing O\&M, especially near the end of the performance period. Seek legal, technical, and tax advice regarding end-of-contract ownership transfer-both prior to executing the contract and during negotiations at the end of the contract term. Other recommendations include:

1. Avoid hazardous materials.

2. Use recoverable/recyclable materials.

3. Recycle PV modules and other recyclable materials.

4. Include contract terms regarding neglect of O\&M late in the contract term.

5. Negotiate contract terms regarding the disposition of a system at end of the contract

6. Plant for a contingency if the contractor is out of business or neglects the project.

\subsection{Avoid Hazardous Materials}

Human Health Risk Assessment Methods for PV Part 2 - Breakage Risks and Part 3 - Module Disposal Risk, two reports by an interdisciplinary task force, do not motivate concern over endof-life management for PV, nor PV waste, from a toxicity/hazardous materials standpoint. The studies find that risks from lead, cadmium, and selenium are well below referenced risk thresholds even under extremely worst-case assumptions, such as modules left in the field that have broken glass (IEA PVPS Task 12 2020). Still, there are a variety of PV module manufacturing technologies and methods, some that involve more hazardous materials and others that involve less. Avoiding hazardous materials, where possible, aligns with approaches to sustainability and cost avoidance.

Hazardous materials can be in wafer cells, thin-film cells, solder, cover glass, and backsheets. A PV module might contain approximately 10 grams of lead per module, mostly in the solder but also in the cell metallization layer. Thin-film cells made of cadmium-telluride contain both toxic metals and are stable when bound together as a compound and encapsulated; however, when exposed to the acidic environment of a landfill or in fire, these toxic compounds can be liberated (Ramos-Ruiz et al 2017). Thin-film cells made of copper indium selenide contain selenium, which can be toxic when oxidized. Some cover glass manufacturers add antimonyto provide the high transparency required in the solar spectrum-which can leach out in an acidic landfill. Back sheets are often made of fluoropolymers because they are stable and inherently flame-retardant, but they can produce toxic gases in a fire (Wirth 2020).

Hazardous materials can also appear in components other than the PV modules. The solder in other electronic devices, such as inverters, might contain lead; and the plastic insulation on wires might include lead to make them more flexible and to make the color last longer.

A specifier can find products with reduced amounts of hazardous materials or even avoid some of them altogether (Nussey 2020). A specifier will also consider price, availability, and performance when avoiding the hazardous substances. For example, lead-tin solder-typically $63 \%$ tin and $37 \%$ lead - could be replaced with a combination of $95.5 \%$ tin, 3.9\% silver, and $0.6 \%$ copper (although silver can also be toxic to aquatic life). Another emerging alternative to lead solder would be electrically conductive adhesives, which are created by suspending 
metallic particles in a polymer glue with other additives (Black 2005). Avoiding hazardous materials in the first place reduces all subsequent risk - whether the modules are accidentally shattered in the field, incinerated in fire, disposed of in a landfill, or recycled to reduce overall environmental impact.

\subsection{Use Recoverable/Recyclable Materials}

There are several measures that a designer or specifier can consider to increase the content of a PV system that can be recycled. Driven steel piles (same as hold the PV array) can be used to support new equipment that might otherwise be mounted on concrete pads. Both aluminum and steel are widely recycled, and recoverability can be enhanced if these are not intimately comingled with or permanently fastened to other materials. Concrete can also be recycled as aggregate. If using plastic, consider plastic types that are recycled and more amenable to recycling. High-density polyethylene (Type 2 plastic) is widely recycled (30\% is recycled in the United States) but has performance (sunlight resistance and temperature range) similar to polyvinyl chloride (Type 3), which is not recycled (only 1\% in the United States) and can release toxic compounds in a fire (Seaman 2012). Recyclability strongly depends on the form that the material is in. Consider how materials can be separated into recyclable commodities in the design and specifications for a new PV system.

\subsection{Recycle Photovoltaic Modules and Other Recyclable Materials}

PV modules and system components can be recycled to recover materials that can be sold into commodity markets (Curtis et al. 2021a; Salim et al. 2019; Libby and Shaw 2018; Weckend, Wade, and Heath 2016). PV panels recycling can recover materials such as indium, glass, silicon, tellurium, silver, and copper (Curtis et al. 2021a; Mulvaney 2019; Heath et al. 2020; Salim et al. 2019; SEIA 2019a; Xu, Li, and Tan 2018; Dominguez and Geyer 2017; Weckend, Wade, and Heath 2016; SEIA 2019a). Recycling PV system components — such as the ballasts, frames, mounting equipment, junction box, and wires - can recover aluminum, copper, steel, and plastic (Mulvaney 2019; Heath et al. 2020). A 2016 study found that recycling PV modules has the potential to result in a $\$ 60$ million U.S. industry by 2030 and a $\$ 2$ billion industry by 2050 (Weckend, Wade, and Heath 2016). Recyclability strongly depends on the form that the material is in. Materials in the form of bottles and cans are easy for recyclers to handle, whereas the form that materials would take in an existing PV installation might not be easily recyclable.

\subsection{Include End of PV Performance Period Issues in Contract Terms}

It is important - and challenging — to specify the plan for the end of the performance period in the initial contract documents. It is important because the system might have considerable value either as an ongoing asset or as salvage value, and it might also be a liability in terms of removal and disposal. It is challenging because it is not easy to foresee what the best solution will be for the end of the performance period in 25 or 30 years. For example, some contacts have required that the systems be removed, and the ground be restored to its original condition at the end of a 20 -year contract period, but if the systems are still producing $80 \%$ of their initial power, that contract precludes refurbishment or repowering and misses out on any benefit of keeping the systems operating during a longer performance period, which might be in everyone's interest. It might be possible to amend a contract if both parties agree. A decommissioning date might be extended by, for example, 5 years without necessarily changing the roles and responsibilities of the parties. 
Performance contracts often describe the purchase of solar power during some time period at a pre-negotiated $\$ / \mathrm{kWh}$ annual power purchase price (with or without an annual escalator). Near the end of the term of a performance contact, there will not be time to recover investments in major repairs or even for preventative O\&M. Although tax laws in the United States require that this transfer of ownership occurs at FMV, the contractor will have already amortized any debt, and the value of the system could be fully depreciated, and thus the contractor might not be expecting any value at the end of the performance period; thus, it is prudent to include with such PPAs a clause that clearly states the system shall be properly maintained during the entire term of the contract in terms of power production, appearance, and safety - and so that it is in a predictable condition when actions are taken at the end of the performance period.

\subsection{Plan a Contingency if the Responsible Party Is Unable to Perform Decommissioning}

The decommissioning clause should also address the possibility that the developer might fail to deliver the decommissioning plan. At least one case has occurred where the contracting partner declared bankruptcy and was unable to perform the work of removing the system and restoring the site ground cover. Most jurisdictions would consider an inoperable PV system abandoned and might have the authority to remove the system and place a lien on the value of the property.

The financial instruments to protect against such liability include decommissioning trusts; escrow accounts; removal, surety, or performance bonds; and letters of credit (NYSERDA 2020). These instruments would pay if a third party had to be hired to perform the work. The bond would be paid for by the responsible party initially as part of the contract closure, and it might need to be renewed during the term of the PV system lifetime or until decommissioning is complete. Changes in the cost of decommissioning (for example, if landfill tipping fees increased) might require revisions to the bond amount. The bond could cover whatever work is described in the bond, and it is usually written to cover high-concern items, such as taking back hazardous materials for recycling. Bonds are a form of insurance, and insurance providers might cover such liability under other insurance policy types. 


\section{Conclusion}

Decisions affecting alternatives at the end of the performance period for a PV plant are often limited by local regulations regarding permitting and land-use planning and state or federal regulations regarding handling and disposal of waste. Decisions regarding the final disposition of a system are often made much earlier - in the development of contracts, permits, and agreements regarding construction of the plant in the first place. Because a main driver of the PV market is concern about environmental sustainability, everyone in the PV industry-from PV module manufacturers, to project developers, to project owners and financiers, to designers and specifiers, to O\&M providers - needs to ensure that liabilities such as hazardous materials are avoided and that the provisions made at the end of the performance period extract the most economic value and entail the least environmental impact as possible — or at least comply with all environmental regulations. In many cases, the site control, utility interconnection, and civil improvements such as access roads and stormwater drainage will have a high value and could justify repowering with new PV modules and inverters.

Alternatives at the end of an expected performance period include extending the performance period, refurbishing the system, repowering the system, or decommissioning and removing a system. Extending performance period entails no capital investment but suffers from degraded performance and high O\&M cost of the aged equipment. Refurbishment fixes any problems revealed in an inspection and may recover a portion of underperformance but still has high O\&M costs. Repowering with new PV modules and inverter restores or even increases original performance and reduces O\&M cost with new equipment and warranties. Decommissioning entails an expense to properly remove all equipment and restore the site for another use. The best of these alternatives is often site-specific, depending on the details of that situation - such as estimated costs to refurbish or repower and projected revenue from continued operations.

Tax implications can drive decisions. Contracts are often structured so that projects are eligible for tax credits and depreciation. Two key tax considerations are: (1) ownership must transfer at fair market value to be eligible for the federal ITC, and (2) in a repowering, at least $80 \%$ of the value of the repowered plant must be new to be eligible for the ITC.

Under all circumstances local, state, and federal regulations must be observed. Regulations regarding land-use plans might require that decommissioning plans and financial resources to accomplish decommissioning be established in the initial permitting process. Federal and state regulations regarding transportation, storage, and disposal of waste must be observed. Recycling and disposing of PV systems equipment and materials at the end of their performance period can provide a financial benefit to the owner and can uphold goals of sustainability. 


\section{References}

ASTM. 2012. ASTM Standards on Building Economics, $7^{\text {th }}$ Edition. West Conshohocken, PA.

Barbosa, Cesar. 2020. "New Regulations for End-of-Life PV Modules.” Presented at the California Solar and Storage Association Webinar, November 11, 2020.

Black, Harvey. 2005, "Getting the Lead Out of Electronics." Environmental Health Perspectives 113 (10): A682-A685. https://doi.org/10.1289/ehp.113-a682.

Clean Energy States Alliance (CESA). 2017. Standards and Requirements for Solar Equipment, Installation, and Licensing and Certification: A Guide for States and Municipalities.

Montpelier, VT. https://www.cesa.org/assets/2017-Files/Standards-and-Requirements-for$\underline{\text { Solar.pdf. }}$

Curtis, Taylor L., Garvin Heath, Heather Buchanan, and Ligia Smith. 2021a. A Circular Economy for Solar Photovoltaic System Materials: Drivers, Barriers, and Enables for US Policy Considerations. Golden, CO: National Renewable Energy Laboratory.

Curtis, Taylor L., Garvin Heath, Heather Buchanan, Stephan Shaw, and Ben Kaldunski. $2021 b$. Solar Photovoltaic Recycling: A Survey of U.S. Policies and Initiatives" (NREL/6A20-74124). Golden, CO: National Renewable Energy Laboratory.

Dominguez, Adriana, and Roland Geyer. 2017. "Photovoltaic Waste Assessment in Mexico." Resources, Conservation, and Recycling Journal 127 (December): 29-41. https://doi.org/10.1016/j.resconrec.2017.08.013.

Electronic Product Environmental Assessment Tool (EPEAT). Accessed December 23, 2020. https://epeat.net/.

Feldman, David, Eric O’Shaughnessy, and Robert Margolis. 2020. “Q3/Q4 2019 Solar Industry Update" (NREL/PR-6A20-76158). Presented on February 18, 2020. Accessed November 12, 2020. https://www.nrel.gov/docs/fy20osti/76158.pdf.

Heath, Garvin A., Timothy J. Silverman, Michael Kempe, Michael Deceglie, Dwarakanath Ravikumar, Timothy Remo, Hao Cui, Parikhit Sinha, Cara Libby, Stephanie Shaw, Keiichi Komoto, Karsten Wambach, Evelyn Butler, Teresa Barnes, and Andreas Wade. 2020.

"Research and Development Priorities for Silicon Photovoltaic Module Recycling to Support a Circular Economy." Nature Energy 5 (July): 502-510. https://doi.org/10.1038/s41560-020$\underline{0645-2 .}$

Institute of Electrical and Electronics Engineers (IEEE). 2018. IEEE 1547-2018 - Standard for Interconnection and Interoperability of Distributed Energy Resources with Associated Electric Power Systems Interfaces.” Piscataway, New York. https://standards.ieee.org/standard/15472018.html.

Internal Revenue Service (IRS). 2018. Internal Revenue Service Notice 2018-59. Accessed December 28,2020. https://www.irs.gov/pub/irs-drop/n-18-59.pdf accessed 12/29/2020. 
International Energy Agency (IEA) Photovoltaic Power Systems Programme (PVPS) Task 12. 2020. Human Health Risk Assessment Methods for PV Part 2 - Breakage Risks. Accessed January 27, 2021. https://iea-pvps.org/key-topics/iea-pvps-t12-15 human-health-riskassessment-methods-for-pv-part-2/.

International Energy Agency (IEA) Photovoltaic Power Systems Programme (PVPS) Task 12. 2020. Human Health Risk Assessment Methods for PV Part 3: Module Disposal Risks. Accessed January 27, 2021. https://iea-pvps.org/key-topics/human-health-risk-assessmentmethods-for-pv-part-3-module-disposal-risks/.

International Renewable Energy Agency (IRENA). 2016. End-of-Life Management: Solar Photovoltaic Panels (ISBN 978-92-95111-98-1). International Renewable Energy Agency and IEA Photovoltaic Power Systems Program. https://www.irena.org/publications/2016/Jun/Endof-life-management-Solar-Photovoltaic-Panels.

Lavappa, Priya D., and Joshua D. Kneifel. 2019. NISTIR 85-3273-34: Energy Price Indices and Discount Factors for Life-Cycle Cost Analysis - 2019, Annual Supplement to NIST Handbook 135. Gaithersburg, MD: National Institute of Standards and Technology. https://doi.org/10.6028/NIST.IR.85-3273-34.

Leslie, Joswin. 2018. "Dependence of Toxicity Test Results on Sample Removal Methods of PV Modules.” Master's thesis, Arizona State University. https://repository.asu.edu/attachments/207447/content/Leslie asu 0010N 18113.pdf.

Libby, Cara, and Stephanie Shaw. 2018. Solar PV Module End of Life: Options and Knowledge Gaps for Utility-Scale Plants (EPRI Technical Update Report 3002014407). Palo Alto, CA: Electric Power Research Institute.

Lundt, Billy. 2019. "How to Decommission a Solar Array, and Why It's Important to Plan Ahead." Solar Power World, March 11, 2019. Accessed October 26, 2020. https://www.solarpowerworldonline.com/2019/03/how-to-decommission-a-solar-array-andwhy-its-important-to-plan-ahead/.

Mulvaney, Dustin. 2019. Solar Power: Innovation, Sustainability, and Environmental Justice. Oakland, CA: University of California Press. www.jstor.org/stable/j.ctvd1c6zh.

National Renewable Energy Laboratory (NREL). 2020. "Annual Technology Baseline." Assessed December 29, 2020. https://atb.nrel.gov/electricity/2020/index.php? $\mathrm{t}=\mathrm{sr}$.

New York State Energy Research and Development Authority (NYSERDA). 2020. Decommissioning Solar Panel Systems. New York, NY. https://www.nyserda.ny.gov/$\underline{\text { /media/NYSun/files/Decommissioning-Solar-Systems.pdf accessed 10/22/2020. }}$.

Nussey, Bill. 2020. Are Solar Panels Really Full of Toxic Materials Like Cadmium and Lead? The Energy Project. Accessed October 20, 2020. https://www.freeingenergy.com/are-solarpanels-really-full-of-toxic-materials-like-cadmium-and-lead/. 
NSF International. 2019. NSF International Standard/American National Standard: NSF/ANSI 457 - 2019: Sustainability Leadership Standard for Photovoltaic Modules and Photovoltaic Inverters. Ann Arbor, MI. Assessed December 23, 2020. https://greenelectronicscouncil.org/wp-content/uploads/2019/12/NSF-457-2019.pdf.

Ramos-Ruiz, Adriana, Jean V. Wilkening, James A. Field, and Reyes Sierra-Alvarez. 2017. "Leaching of Cadmium and Tellurium from Cadmium Telluride (CdTe) Thin-Film Solar Panels Under Simulated Landfill Conditions." Journal of Hazardous Materials 336 (Aug.): 57-64. https://doi.org/10.1016/j.jhazmat.2017.04.052.

Salim, Hengky K., Rodney A. Stewart, Oz Sahin, and Michael Dudley. 2019. "Drivers, Barriers and Enablers to End-of-Life Management of Solar Photovoltaic and Battery Energy Storage Systems: A Systematic Literature Review." Journal of Cleaner Production 211 (February): 537-54. https://doi.org/10.1016/j.jclepro.2018.11.229.

Seaman, Greg. 2012. "Plastic by the Numbers." Eartheasy, May 2, 2012. Accessed October 22, 2020. https://learn.eartheasy.com/articles/plastics-by-the-numbers/.

Solar Energy Industries Association (SEIA). 2019a. "End-of-Life Considerations for Solar Photovoltaics." May 2019. https://www.seia.org/sites/default/files/2019-05/SEIA-EOLConsiderations-PV-Factsheet-May2019.pdf.

—. 2019b. "SEIA National PV Recycling Program." https://www.seia.org/initiatives/seianational-pv-recycling-program.

_. 2019c. "SEIA PV End-of-Life Management." https://www.seia.org/sites/default/files/SEIA-PV-Recycling-Checklist.pdf.

U.S. Department of Energy. 2020. "Guide to the Federal Investment Tax Credit for Commercial Solar Photovoltaics" (DOE/EE-2006). Accessed December 31, 2020.

https://www.energy.gov/sites/prod/files/2020/01/f70/Guide\%20to\%20the \%20Federal\%20Invest ment $\% 20$ Tax $\% 20$ Credit $\% 20$ for $\% 20$ Commercial $\% 20$ Solar\%20PV.pdf.

U.S. Environmental Protection Agency (EPA). 2019a. "State Universal Waste Programs in the United States." Hazardous Waste. Last modified August 30, 2019. https://www.epa.gov/hw/state-universal-waste-programs-united-states.

2019b. "State Authorization under the Resource Conservation and Recovery Act (RCRA)." Last modified May 21, 2019. https://www.epa.gov/rcra/state-authorization-underresource-conservation-and-recovery-act-rcra.

Walker, Andy, Eric Lockhart, Jal Desai, Kristen Ardani, Geoff Klise, Olga Lavrova, Tom Tansy, Jessie Deot, Bob Fox, and Anil Pochiraju. 2020. Model of Operation-and Maintenance Costs for Photovoltaic Systems (NREL/TP-5C00-74840). Golden, CO: National Renewable Energy Laboratory. https://www.nrel.gov/docs/fy20osti/74840.pdf. 
Weckend, Stephanie, Andreas Wade, and Garvin Heath. End-of-Life Management: Solar Photovoltaic Panels (IEA-PVPS Report Number T12-06:2016). International Renewable Energy Agency and International Energy Agency Photovoltaic Power Systems. http://ieapvps.org/fileadmin/dam/public/report/technical/IRENA_IEAPVPS_End-ofLife Solar_PV_Panels_2016.pdf.

Wirth, Harry. 2020. "Recent Facts About Photovoltaics in Germany." Data and Facts.

Fraunhofer ISE. Last updated June 10, 2020.

https://www.ise.fraunhofer.de/en/publications/studies/recent-facts-about-pv-in-germany.html accessed 10/20/2020

Xu, Yan, Jinhui Li, and Quanyin Tan. 2018. "Global Status of Recycling Waste Solar Panels: A Review." Waste Management 75 (February): 450-58.

https://www.researchgate.net/publication/323269505_Global_status_of_recycling_waste_solar_ panels_A_review. 